\title{
Teacher Professional Development: EFL Teachers' Experiences in the Republic of Benin
}

\author{
Juvenale Patinvoh Agbayahoun ${ }^{1}$ \\ ${ }^{1}$ Teacher Training College, University of Porto-Novo, Republic of Benin \\ Correspondence: Juvenale Patinvoh Agbayahoun, Teacher Training College, University of Porto-Novo, Republic \\ of Benin. E-mail: dossa0259@yahoo.com
}

Received: March 21, 2016 Accepted: May 27, 2016 Online Published: July 13, 2016

doi:10.5539/ijel.v6n4p144 URL: http://dx.doi.org/10.5539/ijel.v6n4p144

\begin{abstract}
Using a survey, this study examines EFL teachers' views on professional development, the models of teacher development they are familiar with, and their experiences in the area. The study also inquires into the teachers' knowledge and opinions about inquiry-based teaching. The results indicate that though the EFL teachers often have the opportunity to participate in teacher development activities, these activities do not enable them to develop the skill of reflection and action on practice as they are patterned on top-down models of teacher development and happen in a one-shot workshop-style. Other teacher development activities such as action-research, reading research findings in the field, peer observation, mentoring, or teacher networking are unfamiliar to them. While the participant EFL teachers acknowledged that the top-down teacher development activities give them exposure to informative input, they also reported that such activities, paradoxically, have little impact on their teaching and students' learning. Most of them acknowledged having very little knowledge of teacher development activities that involve self-intiative and autonomy, and they expressed interest in learning about and trying action-research in their classrooms.
\end{abstract}

Keywords: action-research, inquiry-based teaching, reflective practice, teacher learning, teacher professional development

\section{Introduction}

In almost all areas of education, when it comes to teacher professional development, the focus is, in most cases, rather put on the content teachers need to learn in order to improve their knowledge of subject matter and of teaching practice. Little attention is often granted to how they actually learn. Some studies that have attempted to assess the impact of teacher development initiatives on classroom practices have yielded unsatisfactory results. Although the majority of the participant teachers involved in those studies acknowledged participating in professional development activities in their professional settings, they found those initiatives useless (e.g., Darling-Hammond, Wei, Andree, Richardson, \& Orphanos, 2009). Thus, the real issue is not that teachers are not provided with professional development, but that the initiatives are ineffective at changing their classroom practices and student learning.

In the Republic of Benin, the current approach to EFL teaching and learning is the competency-based approach. This teaching/learning approach requires that learners be able to demonstrate communicative competence in a variety of real life situations. Therefore, a special attention should be given to the nature of the content, the way it is presented in the language class, the support material used for effective student learning to take place, and the way students' language ability is assessed. To reach this goal, teachers have to learn new teaching practices for significant changes to take place in the language classroom. Teacher development program designers must consider not only what teachers need to learn, but more importantly, how they learn and adopt new techniques, and structure teacher development programs accordingly. Unfortunately, at present, one-time workshops are the most prevalent model of teacher development initiative that Benin secondary school teachers are given exposure to at the beginning of each academic year. Such workshops do not yield much change in teacher practice and student achievement as English language classes continue to be the stage of one-man shows where learners have little chance to reach the claim of the competency-based approach, that is, the acquisition of communicative competence. Therefore, new approaches to teacher learning and development need to be developed to create real changes in teachers' practices and to improve students' achievement in EFL learning. The main purpose of this 
study is to provide a research-based answer to how EFL teacher development programs should be structured in Benin secondary schools in order to promote effective changes in EFL teaching practices and to improve student learning.

\section{Literature Review}

\subsection{Review of Research on Effective Teacher Development}

Previous research in the area of teacher learning and professional development has pointed to the following realities concerning how teachers learn and achieve professional growth: the influence of teachers' beliefs, the challenge of the implementation phase, and the impact of the length of teacher development programs.

\subsubsection{The Influence of Teachers' Beliefs}

With regard to this reality, a body of research conducted in the area of language teaching and language teacher education has revealed that teachers' previous experiences as learners, their beliefs about teaching, and their school culture influence their pedagogical decisions and practices much more than teacher development course contents. Though these courses may improve their understanding and use of some job-related concepts, they have no impact on their actions in the classroom (Johnson, 1994; Richards, Ho, \& Giblin, 1996). Other studies that focused on teacher belief change have shown that teachers change their underlying beliefs about how to teach something after they see successful learning occurring in their classrooms (e.g., Guskey, 2002; Tsang, 2004; Van den Berg, 2002). Therefore, teachers' existing beliefs constitute a crucial variable that should receive a special attention in any teacher education program.

\subsubsection{The Challenge of the Implementation Phase}

Another aspect of teacher learning and professional growth relates to a phenomenon referred to as "the implementation dip" (Fullan, 2001). The findings from previous research have indicated that learning about a teaching method is not as difficult as actually implementing it. Fullan (2001) argues that the area of greatest struggle is not in learning a new skill, but in implementing it. According to Joyce \& Showers (2002), the teacher's mastery of a new skill takes, on average, 20 separate instances of practice and that number may increase if the skill is complex. This striking reality requires that teachers be provided with adequate support during the implementation phase, especially when they are implementing a new method brought about by a reform, in order to enable them to achieve effective professional development.

\subsubsection{The Impact of the Length of the Teacher Development Programs}

A third aspect of teacher learning and development pertains to the length of the teacher development programs. Results of previous research also reveal that the one-shot teacher development workshops commonly held in schools have no effect. They do not change teacher practices, neither do they increase student learning (Darling-Hammond et al., 2009; Yoon, Duncan, Lee, Scarloss, \& Shapley, 2007). In these workshops, it is often assumed that the only challenge facing teachers is a lack of knowledge of effective teaching practices, and the workshops will help teachers fill this knowledge gap. It is also assumed that once this knowledge gap is filled, teachers will be able to change. According to Yoon et al. (2007) only lengthy, intensive professional development programs impact teacher practices and student achievement. Professional development can no longer just be about providing teachers with the basic knowledge about a teaching methodology. Instead, it must promote change in the teacher's practice and lead to increases in student learning. Creating this type of teacher development is one of the biggest challenges educational authorities in Benin face.

\subsection{EFL Teacher Development: Some Research Considerations}

\subsubsection{Models of Teacher Professional Development}

Research distinguishes between top-down and bottom-up models of teacher professional development (Johnson, 2006; Kumaravadivelu, 2003; Richards, 2008; Richards \& Farrell, 2005, Roux \& Mendoza Valladares, 2014). The former, which consists in the transmission of knowledge about what teachers need to know and be able to do, focuses on training teachers to use teaching approaches or methods. Generally, knowledge is transmitted to teachers by specialists or experts in the field through workshops or a short-term training. Though this model gives teachers exposure to pedagogical knowledge, they often find the content of the training irrelevant to the realities of their classrooms. Therefore, they go back to their old teaching practices upon completion of the training. In the second model, teachers are given the opportunity to construct their knowledge of teaching through ongoing inquiry and reflective practice. It consists of a long-term action aiming at encouraging the teacher to engage in ongoing reflection on his teaching with the view to inquiring into and learning about his own teaching and improving his students' learning (Burns, 2000; Geyer, 2008). 


\subsubsection{Inquiry-Based Teacher Development Activities}

Effective teacher learning and growth depends on teachers' willingness to engage in ongoing inquiry-based professional development. Richards \& Farell (2005) define inquiry-based professional development as the teacher's ongoing reflection and action on his teaching with the view to finding solutions to practical problems or issues that puzzle him about his teaching through action-research or classroom research in order to improve and/or renew his knowledge and professional skills. Many researchers have proved the value of teachers' inquiry into their teaching practices as a crucial variable of their professional growth (Zhang, Lundeberg, McConnell, Koehler, \& Eberhardt, 2010). They consider classroom research as an effective way whereby teachers can enhance their professional development through reflection on the teaching action (Cabaroglu, 2014; Cochran-Smith \& Lytle, 1999). Borg (2010) advocates that teachers adopt an inquisitive stance toward their own teaching in order to understand what happens in their classrooms and the effects of their actions on students' learning. Therefore, it is suggested by research that they observe classroom events, detect the problems, and think about solutions through ongoing reflection on their practices. In other words, they should be reflective practitioners for effective teaching and learning to take place in their classrooms (Kumaravadivelu, 2003; Schön, 1995). This requires that they develop not only reflection skills, but also self-observation and self-assessment skills. Unfortunately, in most cases, teachers are either ignorant of the value of classroom research, or simply consider it as a time consuming activity.

In the light of these research considerations about effective EFL teacher development, the study examines the current teacher development initiatives in Benin secondary schools. It inquires into EFL teachers' professional development experiences, their opinions about these experiences, as well as their knowledge and opinions about research-based professional development initiatives that involve teacher autonomy.

\section{Method}

\subsection{Instrument, Data Collection and Analysis}

The data for this study were collected through a 10-item questionnaire written in English and addressed to a group of 200 secondary school EFL teachers during the academic year 2015-2016. Data collection operations took nine weeks. These data were analyzed in terms of percentages.

\subsection{Participants}

Out of the 200 EFL teachers who received the questionnaire, 157 actually participated in the survey by completing and returning the questionnaire sheet, which represents $78.5 \%$ return rate. They are affiliated to two of the six state departments of secondary education, located in the southern part of the country. The participants are $69(43.94 \%)$ male and $88(56.05 \%)$ female teachers. Most of them (82.80\%) are between 25 and 55 years old. Only a few $(17.19 \%)$ are younger than 25 or older than 55 . More than a half $(60.5 \%)$ is qualified for the teaching profession. They are holders of an English language teaching certificate. The remaining teachers (39.49\%) do not have any professional degree in EFL teaching, but are doing the job with an academic degree in English language. The majority $(80.89 \%)$ reported having a teaching work load of 20 hours a week or more. The remaining (19.10\%) teach 18 hours per week or less. As far as their EFL teaching experiences are concerned, about two thirds of the participants (64.96\%) reported years of EFL teaching experiences of 6 years or more while $55(35.03 \%)$ have 5 years of teaching experience or less.

\section{Results}

This article focuses on the participants' responses to items 6 through 10 in the questionnaire addressed to them (see Appendix A). These are the items that elicited from them information related to their experiences with professional development, their opinions about the professional development activities they are familiar with, and their knowledge and opinions about inquiry-based teaching. The first five items served to collect background information about them.

\subsection{Teachers' Experiences with Professional Development}

To collect information related to the participant EFL teachers' experiences with professional development, an item of the questionnaire inquired into the activities they had participated in during the year previous to the study and provided the following set of response options to choose from: state organised yearly training seminars, TEFL degree courses, compulsory weekly school-based teacher development workshops, conferences, peer observation, teacher networking, classroom research, portfolio construction, coaching/mentoring, and professional learning communities.

As Table 1 shows, all 157 participants (100\%) attended the compulsory weekly school-based teacher 
development workshops. One hundred and twenty-nine of them $(82.16 \%)$ attended the state organised yearly teacher training seminars, and $28(17.83 \%)$ did not. These training seminars were one-shot top-down teacher development initiatives in which the participants were exposed to a teaching method or strategy. As mentioned above, 62 of the participants (39.49\%) are not qualified for the profession. Among them, 18 (11.46\%) enrolled in a one-year TEFL degree program during the year previous to the study to get adequate qualification for the profession. The TEFL courses in this program followed a top-down model of teacher training and led to certification in EFL teaching. None of the 157 participants $(0 \%)$ had experience with professional development activities such as conferences, peer observation, coaching, monitoring, action-research, portfolio construction, teacher networking, and involvement in teacher professional learning communities.

Table 1. Participation in professional development activities in the year previous to the study

\begin{tabular}{llll}
\hline Professional development model & Professional development activities & Number of participants & Percentages \\
\hline Top-down (knowledge & State organised training seminars & 129 & $82.16 \%$ \\
transmission model) & TEFL degree courses & 18 & $11.46 \%$ \\
\hline Bottom-up (knowledge & School-based teacher development & 157 & $100 \%$ \\
construction model) & workshops & & $0 \%$ \\
& Conferences & 00 & $0 \%$ \\
& Peer observation & 00 & $0 \%$ \\
& Coaching/monitoring & 00 & $0 \%$ \\
& Action-research & 00 & $0 \%$ \\
& Portfolio construction & 00 & $0 \%$ \\
& Teacher networking & 00 & $0 \%$ \\
& Involvement in professional learning & 00 & \\
& communities & & \\
\hline
\end{tabular}

Note. $\mathrm{N}=157$.

The information in the table above indicates that all the participant EFL teachers took part in a teacher development activity in the year preceding the survey. While 147 (93.63\%) are familiar with the types of initiatives that belong to the top-down knowledge transmission model of teacher development, all of them (100\%) also have experience, but to a limited extent, with the bottom-up model of teacher development, that is, through the compulsory weekly school-based teacher development workshops only. In these workshops, they are involved in collaborative reflection and discussion about issues related to their classroom teaching and realities. Other teacher development activities that involve autonomy, self-initiative, ongoing reflection, and inquiry into their teaching are unfamiliar to them.

\subsection{Teachers' Opinions about Their Professional Development Experiences}

Another item of the questionnaire requested that the participant EFL teachers indicate the level of impact of the different professional development activities they took part in during the year previous to the study on their teaching. A four-dimensional rating scale including the following categories: no impact, low impact, moderate impact, considerable impact was provided to them for the purpose. Table 2 shows the results for this item. The school-based teacher development workshops, an activity that all $157(100 \%)$ participant teachers took part in during the previous year was marked as having a considerable impact on teaching by $98(62.42 \%)$ of the respondents and a moderate impact by $41(26.11 \%)$ of them. The remaining $18(11.46 \%)$ respondents indicated that these workshops have a low impact on their teaching. As far as the state organised seminars are concerned, 104 out of the 129 respondents who marked this response option consider that it has a low impact on their teaching while 25 think that it has no impact. As for the TEFL degree courses, most of the teachers who attended those courses (11 out of 18) marked them as having no impact on their teaching, and 7 perceive a low impact in them. 
Table 2. The teachers' perceived impact of the professional development activities they took part in on their EFL teaching

\begin{tabular}{|c|c|c|c|c|c|c|}
\hline \multirow[t]{2}{*}{ Activities } & \multirow{2}{*}{$\begin{array}{l}\text { Professional } \\
\text { development model }\end{array}$} & \multirow{2}{*}{$\begin{array}{l}\text { Number of participants } \\
\text { who marked the activity }\end{array}$} & \multicolumn{4}{|c|}{ Level of impact } \\
\hline & & & None & Low & Moderate & Considerable \\
\hline $\begin{array}{l}\text { State organised } \\
\text { training seminars }\end{array}$ & $\begin{array}{l}\text { Top-down (knowledge } \\
\text { transmission) }\end{array}$ & $129(82.16 \%)$ & $\begin{array}{l}25 \\
(15.92 \%) \\
\end{array}$ & $\begin{array}{l}104 \\
(66.24 \%) \\
\end{array}$ & & \\
\hline TEFL degree courses & & $\begin{array}{l}18 \\
(11.46 \%) \\
\end{array}$ & $\begin{array}{l}11 \\
(7 \%) \\
\end{array}$ & $\begin{array}{l}7 \\
(4.45 \%) \\
\end{array}$ & & \\
\hline $\begin{array}{l}\text { School-based teacher } \\
\text { development } \\
\text { workshops }\end{array}$ & $\begin{array}{l}\text { Bottom-up } \\
\text { (knowledge } \\
\text { construction) }\end{array}$ & $157(100 \%)$ & & $\begin{array}{l}18 \\
(11.46 \%)\end{array}$ & $\begin{array}{l}41 \\
(26.11 \%)\end{array}$ & $\begin{array}{l}98 \\
(62.42 \%)\end{array}$ \\
\hline
\end{tabular}

Note. $\mathrm{N}=157$.

As the results in the table above indicate, the activity that belongs to the knowledge construction model of teacher professional development is perceived by the participant EFL teachers to have a greater impact on their teaching than the other two types of activities in which knowledge transmission is the pedagogical model followed.

\subsection{Teachers' Opinions about Professional Development Activities}

To inquire into the participant EFL teachers' opinions about their professional growth, an item of the questionnaire focused on what they considered most important for effective EFL teaching. A list of activities was provided for them to mark. This list included the following activities: planning good lessons, mastery of the competency-based approach to EFL teaching, creating a nurturing classroom climate, designing adequate teaching materials, good command of the target language, peer colaboration, reflective practice, attending to learners' needs, reading up-to-date research in EFL teaching, inquiring into one's teaching. They were required to select from the list two activities that they considered most important for effective EFL teaching (the first most important and the second most important). Among the response options, three activities have been marked by the participants as the first most important activity conducive to effective EFL teaching: planning good lessons was marked by 152 of the participants (96.81\%), mastery of the competency-based approach was the response option selected by three of them (1.91\%), and creating a nurturing classroom climate was selected by the remaining two participants (1.27\%). As for the teachers' choices of the second activity that they consider most important, the results in table 3 show the activities chosen followed by the number of respondents who marked each of them and the corresponding percentage.

Table 3. The teachers' choices of two most important activities for effective EFL teaching

\begin{tabular}{lll}
\hline Activities & \multicolumn{2}{c}{ Order of Importance } \\
\cline { 2 - 3 } & First most important & Second most important \\
\hline Planning good lessons & 152 & 00 \\
& $(96.81 \%)$ & $(0 \%)$ \\
\hline Mastery of the competency-based approach to & 3 & 87 \\
EFL teaching & $(1.91 \%)$ & $(55.41 \%)$ \\
\hline Creating a nurturing classroom climate & 2 & 27 \\
& $(1.27 \%)$ & $(17.19 \%)$ \\
\hline Designing adequate teaching materials & 00 & 15 \\
& $(0 \%)$ & $(9.55 \%)$ \\
\hline Good command of the target language & 00 & 12 \\
& $(0 \%)$ & $(7.64 \%)$ \\
\hline Peer collaboration & 00 & 8 \\
& $(0 \%)$ & $(5.09 \%)$ \\
\hline Reflective practice & 00 & 5 \\
& $(0 \%)$ & $(3.18 \%)$ \\
\hline Attending to learners' needs & 00 & $(1.91 \%)$ \\
\hline Reading up-to-date research in EFL teaching & $(0 \%)$ & 00 \\
& 00 & $(0 \%)$ \\
\hline Inquiring into one's teaching & $(0 \%)$ & 00 \\
& 00 & $(0 \%)$ \\
\hline
\end{tabular}


As the figures above indicate, planning good lessons is considered by almost all the participant EFL teachers (96.81\%) as a very important variable for effective EFL teaching. It should be noticed that mastery of the competency-based approach, the current teaching/learning approach being implemented in secondary education nationwide in the Republic of Benin, is granted credit too by more than half of the teachers. Besides, in addition to planning good lessons, two other activities that are related to classroom implementation are given some credit by a few of them (creating a nurturing classroom climate and designing adequate teaching materials). This is not the case with the activities that promote teacher learning through self-initiative. For example, reading up-to-date research in EFL teaching and inquiring into one's teaching were granted no credit by the participants.

To have a deeper insight into the participants' points of view about professional development activities, an item of the questionnaire required them to mark the activity they considered would strengthen their EFL teaching. For this purpose, a list of activities was provided. The results reveal the following ranking of the activities basing on the number of the participants who marked them:

Table 4. Knowledge that would strengthen the participant EFL teachers' teaching

\begin{tabular}{lll}
\hline Activites & Number of participants & Percentages \\
\hline Knowledge about the competency-based approach to EFL teaching & 91 & $57.96 \%$ \\
Knowledge about material design for EFL teaching & 26 & $16.56 \%$ \\
Collaborative teacher thinking and problem solving & 17 & $10.82 \%$ \\
Language enhancement program & 16 & $10.19 \%$ \\
knowledge about instructional technology & 5 & $3.18 \%$ \\
Knowledge of the new developments in the field of TEFL & 2 & $1.27 \%$ \\
Action research & 00 & $0 \%$ \\
\hline
\end{tabular}

Note. $\mathrm{N}=157$.

Since the competency-based approach is the current pedagogical approach implemented in Beninese secondary schools for the teaching of all subjects, the teachers think that deepening their knowledge about it would strengthen their EFL teaching performance, which is quite understandable. As the results indicate, classroom research appears to be the last activity in the ranking, being granted no credit by the teachers.

\subsection{Teachers' Knowledge and Opinions about Inquiry-Based Teaching}

Inquiry-based teaching involves investigating one's teaching through the process of collection and analysis of data related to aspects of teaching and learning with the view to documenting classroom experiences, bringing changes in pedagogical practices and improving students' learning. Most teachers, unfortunately, are not familiar with this practice, and even consider it as a difficult task.

In an attempt to explore teachers' knowledge and thinking about inquiry-based teaching in this study, the participants were provided with a series of statements about action-research that they were asked to mark using a scale that includes the following three response options: agree, don't know, disagree. Table 5 shows the statements and the teachers' evaluation.

Table 5. Teachers' knowledge and opinions about inquiry-based teaching

\begin{tabular}{|c|c|c|c|}
\hline Statements & Agree & Don't know & Disagree \\
\hline $\begin{array}{l}\text { Reading TEFL literature can motivate action-research in EFL } \\
\text { classes. }\end{array}$ & (22) $14.01 \%$ & (135) $85.98 \%$ & $(00) 0 \%$ \\
\hline Action-research is necessary for EFL teachers' professional growth & (11) $7 \%$ & (146) $92.99 \%$ & (00) $0 \%$ \\
\hline $\begin{array}{l}\text { Doing action-research helps EFL teachers find solutions to teaching } \\
\text { problems }\end{array}$ & (17) $10.82 \%$ & (140) $89.17 \%$ & (00) $0 \%$ \\
\hline $\begin{array}{l}\text { Doing action-research enables EFL teachers to learn about their own } \\
\text { teaching }\end{array}$ & (18) $11.46 \%$ & (139) $88.53 \%$ & (00) $0 \%$ \\
\hline $\begin{array}{l}\text { Doing action-research helps EFL teachers reflect on their own } \\
\text { teaching }\end{array}$ & (5) $3.18 \%$ & (152) $96.81 \%$ & (00) $0 \%$ \\
\hline Doing action-research helps EFL teachers improve student learning & (27) $17.19 \%$ & (130) $82.80 \%$ & (00) $0 \%$ \\
\hline EFL teachers should be encouraged to do action-research & (32) $20.38 \%$ & (125) $79.61 \%$ & (00) $0 \%$ \\
\hline $\begin{array}{l}\text { Neglecting action-research in EFL teaching can lead to the } \\
\text { professional of the field }\end{array}$ & (00) $0 \%$ & (112) $71.33 \%$ & (45) $28.66 \%$ \\
\hline I am interested in learning about action-research & (130) $82.80 \%$ & (20) $12.73 \%$ & (7) $04.45 \%$ \\
\hline
\end{tabular}


As Table 5 indicates, the concept of action-research and its practice are unfamiliar to the majority of the participant EFL teachers. Most of them, more than the three quarters, are not even aware of its purpose and usefulness for their professional growth and for the development of the field of EFL teaching. Indeed, the results reveal that they know very little about what it entails and its related benefits. This situation might be explained by the fact that reading research reports in the field is not a common practice of Beninese EFL teachers due to the difficult access to internet facilities and to the fact that up-to-date TEFL (Teaching English as a Foreign Language) literature is not available in school and public libraries. It is through reading that teachers will discover the different alternatives available for their growth in the profession. They cannot do action-research if they have no knowledge about what it is and what it entails. Therefore teachers need access to adequate resources to be informed about action-research and how it is carried out. They also need to be given adequate guidance and support to help them improve their teaching. The figures in the table above also reveal that the majority of the participant EFL teachers $(82.80 \%)$ want to know about action-research. Their interest in learning about teaching through classroom research can motivate their decision to try it in their classrooms.

\section{Discussion and Suggestions}

As the results indicate, all the participant EFL teachers took part in professional development activities the year preceding the study. While the large majority $(93.63 \%)$ was involved in a knowledge transmission type of teacher development, all of them (100\%) had also engaged in a knowledge construction model of teacher development through their participation in the compulsory weekly school-based teacher development workshops. Though the teachers acknowledged that these workshops have a considerable impact on their teaching, they also manifested their ignorance of the teacher development activities that involve teacher self-initiative and autonomy. The majority of the participants $(82.80 \%)$ expressed their interest in learning about and developing research abilities, and engaging in autonomous teacher learning and development through classroom research. This aspect of the findings corroborates the outcomes of a study previously carried out in a Mexican context by Roux and Mendoza Valladares (2014) to investigate EFL teachers' professional development experiences. However, contrary to the participants in the present study, those involved in Roux and Mendoza's work were aware of the value of research-based teaching as the majority showed positive views on classroom research.

The findings of the study also reveal that the state organised yearly training seminars prove to be ineffective as they happen in a one-shot workshop-style. This supports the results of previous research that revealed that such workshops commonly held in schools have no effect. They neither change teacher practices, nor increase student learning (Darling-Hammond et al., 2009; Yoon et al., 2007). For effective changes to take place in teachers' practices and students' learning, the following characteristics of effective teacher development programs identified by Darling-Hammond et al. (2009) need to be taken into account in the design and implementation of teacher development initiatives in Benin :

1) They should emphasize practices that promote critical thinking and problem-solving in the classroom.

2) They should cover a significant time period and be carried out on an ongoing basis to enable teachers to translate new knowledge into practice and grapple with implementation problems.

3) They should provide teachers with adequate follow-up and support during the implementation stage in classrooms.

4) They should engage teachers through a variety of approaches and foster their active involvement in the learning activities in order to enable them to make sense of the new knowledge.

5) They should emphasize modeling to help teacher gain a deeper understanding of the new concepts introduced to them during the training.

6) The program content should focus on the teacher's discipline.

7) They should not merely expose teachers to new concepts. Instead, they should lead to a change in teacher's practice and increases in student learning.

Existing literature also suggests the following key professional learning activities as the ones which are likely to induce changes in teachers' classroom practices: keeping updated, experimentation, reflective practice, knowledge sharing, and innovation (Geijsel, Sleegers, Stoel, \& Krüger, 2009; Janssen \& van Yperen, 2004; Kwakman, 2003; Runhaar, 2008). Other researchers suggest a school-based ongoing model of professional development which is grounded in day-to-day teaching practice to enhance teachers' instructional practices and student learning. This model is referred to as job-embedded professional development as it is locally rooted and integrated into the workday (Darling-Hammond \& McLaughlin, 1995; Hawley \& Valli, 1999; Hirsh, 2009). It consists in having teachers assess and find solutions to authentic and immediate problems of practice as part of a cycle of continuous 
improvement. It is an ongoing process that requires active teacher involvement in cooperative, inquiry-based work. This model includes activities such as: action research, classroom observation, mentoring, case discussions, coaching, portfolios, teaching networks, professional learning communities. EFL teachers definitely need a considerable amount of exposure to the knowledge-construction type of teacher development practices. They need to know about and experience activities or practices that promote a more reflective type of professional development.

\section{Conclusion}

While teacher development can be carried out through input sessions in formal training programs, many development opportunities are available for teachers through peer collaboration, communication within the school, informal interactions between teachers, classroom research, and reflection to help them improve their practices. This study examined the professional development opportunities that secondary school EFL teachers had experienced in the Republic of Benin, their opinions about the effects of these teacher development initiatives, and their knowledge and opinions about inquiry-based teaching. The outcomes of the study and the suggestions made are expected to contribute to finding ways to provide adequate support that would help promote effective professional development of secondary education English language teachers in the educational context investigated.

\section{References}

Borg, S. (2010). Language teacher research engagement. Language Teaching, 43(4), 391-429. http://dx.doi.org/10.1017/S0261444810000170

Burns, A. (2000). Facilitating collaborative action research: Some insights from AMEP. Prospect, 15(3), 23-34.

Cabaroglu, N. (2014). Professional development through action- research: Impact on self-efficacy. System, 44, 79-88. http://dx.doi.org/10.1016/j.system.2014.03.003

Cochran-Smith, M., \& Lytle, S. (1999). The teacher research movement: A decade later. Educational Researcher, 28(7), 15-25. http://dx.doi.org/10.3102/0013189X028007015

Darling-Hammond, L., \& McLaughlin, M. W. (1995). Policies that support professional development in an era of reform. Phi Delta Kappan, 76(8), 597-604.

Darling-Hammond, L., Wei, R. C., Andree, A., Richardson, N., \& Orphanos, S. (2009). Professional learning in the learning profession: A status report on teacher development in the United States and abroad. Oxford, OH: National Staff Development Council.

Fullan, M. (2001). Leading in a culture of change. San Franscisco: Jossey-Bass.

Geijsel, F. P., Sleegers, P. J. C., Stoel, R. D., \& Krüger, M. L. (2009). The effects of teacher psychological, school organisational and leadership factors on teachers'professional learning in Dutch schools. The Elementary School Journal, 109(4) 406-427. http://dx.doi.org/10.1086/593940

Geyer, N. (2008). Reflective practices in foreign teacher education: A view through micro and macro windows. Foreign Language Annals, 41(4), 627-638. http://dx.doi.org/10.1111/j.1944-9720.2008.tb03321.x

Guskey, T. R. (2002). Professional development and teacher change. Teachers and Teaching: theory and practice, 8(3), 381-391. http://dx.doi.org/10.1080/135406002100000512

Hawley, W. D., \& Valli, L. (1999). The essentials of effective professional development: A new consensus. In L. Darling-Hammond \& G. Sykes (Eds.), Teaching as the learning profession: Handbook of policy and practice (pp. 127-150). San Francisco: Jossey-Bass.

Hirsh, S. (2009). A new definition. Journal of Staff Development, 30(4), 10-16.

Janssen, O., \& van Yperen, N. W. (2004). Employees'goal orientations, the quality of leader-member exchange, and the outcomes of job performance and job satisfaction. Academy of Management Journal, 47, 368-384. http://dx.doi.org/10.2307/20159587

Johnson, K. (1994). The emerging beliefs and instructional practices of pre-service English as a second language teachers. Teaching and Teacher Education, 10, 439-452. http://dx.doi.org/10.1016/0742-051X(94)90024-8

Johnson, K. (2006). The sociocultural turn and its challenges for second language teacher education. TESOL Quarterly, 40(1), 235-257. http://dx.doi.org/10.2307/40264518

Joyce, B., \& Showers, B. (2002). Student achievement through staff development. New York: National Commission on Teaching and America's Future and Consortium for Policy Research in Education. 
Alexandria, VA: Association for Supervision and Curriculum Development.

Kumaradivelu, B. (2003). Forum: Critical language pedagogy. A post method perspective On English language teaching. World Englishes, 22(4), 539-550. http://dx.doi.org/10.1111/j.1467-971X2003.00317.x

Kwakman, K. (2003). Factors affecting teachers' participation in professional learning activities. Teaching and Teacher Education, 19, 149-170. http://dx.doi.org/ 10.1016/S0742-051X(02)00101-4

Richards, J. C. (2008). Second language teacher education today. RELC Journal, 39(2), 158-177. http://dx.doi.org/10.1177/0033688208092182

Richards, J. C., \& Farrell, T. S. C. (2005). Professional development for language teacher: Strategies for teacher learning. Cambridge: Cambridge University Press. http://dx.doi.org/10.1017/CBO9780511667237

Richards, J. C., Ho, B., \& Giblin, C. (1996). Learning to teach in RSA Cert. In D. Freeman \& J. C. Richards (Eds.), Teacher learning in language teaching (pp. 105-123). Lincolnwood, IL: National Textbook Company.

Roux, R., \& Mendoza Valladares, J. L. (2014). Professional development of Mexican secondary EFL teachers: Views and willingness to engage in classroom research. English Language Teaching, 7(9) http://dx.doi.org/10.5539/elt.v7n9p21

Runhaar, P. (2008). Promoting teachers' professional development. Ipskampe, Enschede: PrintPartners.

Schön, D. (1995). The reflective practitioner: How professionals think in action (2nd ed.). Aldershot, UK: Ashgate Publishing.

Tsang, W. K. (2004). Teachers' personal practical knowledge and interactive decisions. Language Teaching Research, 8(2), 163-198. http://dx.doi.org/ 10.1191/1362168804lr139oa

Van den Berg, R. (2002). Teachers' meaning regarding educational practice. Review of Educational Research, 72(4), 577-625. http://dx.doi.org/10.3102/00346543072004577

Yoon, K. S., Duncan, T., Lee, S. W. Y., Scarloss, B., \& Shapley, K. (2007). Reviewing the evidence on how teacher professional development affects student achievement (Issues and Answers Report, REL 2007 No. 033). Washington, DC: U.S. Department of Education, Regional Educational Laboratory Southwest.

Zhang, M., Lundenberg, M., McConnel, T. J., Koehler, M. J., \& Eberhardt, J. (2010). Using questioning to facilitate discussion of science teaching problems in teacher professional development. The Interdisciplinary Journal of Problem-based Learning, 4(1), 57-82. http://dx.doi.org/10.7771/1541-5015.1097

\section{Appendix A}

\section{Items (Questions) Included in the Questionnaire Addressed to the Participant EFL Teachers}

1. Gender: Male

2. Age:

3. Qualification:

* Professional degree:

4. Years of EFL teaching experience:

5. Grade level(s) currently taught:

6. What professional development activities did you participate in last year?

7. What is the level of impact of each of the activities you marked in item 6 on your teaching?

8. What do you consider as being most important for effective EFL teaching?

9. What type of knowledge would strengthen your teaching?

10. What is your opinion about research-based EFL teaching?

Note. For items 6 through 10, the response options provided for the teachers to mark appear in the tables displaying their responses to each of the questions.

\section{Copyrights}

Copyright for this article is retained by the author(s), with first publication rights granted to the journal.

This is an open-access article distributed under the terms and conditions of the Creative Commons Attribution license (http://creativecommons.org/licenses/by/3.0/). 